\title{
Effect of Row Spacing and Plant Density on the Yield of Faba bean L. Under Very Differentiated Humidity Conditions
}

\author{
Janusz Prusiński ${ }^{1}$ \\ ${ }^{1}$ Department of Agronomy, University of Science and Technology, Bydgoszcz, Poland \\ Correspondence: Janusz Prusiński, Department of Agronomy, University of Science and Technology, Bydgoszcz, \\ Poland. Tel: 011-52-374-9451. E-mail: janusz.prusinski@pbs.edu.pl
}

Received: September 28, 2021

Accepted: November 19, 2021

Online Published: December 15, 2021

doi:10.5539/jas.v14n1p1

URL: https://doi.org/10.5539/jas.v14n1p1

The research is financed by the Polish Ministry of Agriculture and Rural Development.

\begin{abstract}
The research covered Polish low-tannin Faba bean 'Albus', and its yielding depending on the row spacing and plant density under very different humidity conditions across the research years. The mean multi-year faba bean seed yield was $4.01 \mathrm{t} \mathrm{ha}^{-1}$ and it was most correlated with the total rainfall in August and in June-August. Due to a considerable variation in the total rainfall and air temperature, the faba bean seed yield ranged from $0.69-2.14 \mathrm{tha}^{-1}$ in dry years (2018-2019) with high air temperature, from 6.64 to $6.59 \mathrm{ha}^{-1}$ in humid years (2016-2017) with a considerably higher total rainfall and lower air temperature in June-August. There was no significant effect of the row spacing and plant density on the faba bean yielding, except for a significantly lower seed yield in 2019 following the application of the lowest plant density. Out of all the yield structure components, only the number of pods per plant for $60-75$ plants per $\mathrm{m}^{2}$ was significantly lower than for 45 plants. The other yield structure components did not differ significantly due to the factors studied either, except for the LAI, the value of which for a narrow row spacing was significantly higher. There was found a significant correlation between all the plant traits and with the faba bean yield.
\end{abstract}

Keywords: row spacing, plan density, seed yield, yield components

\section{Introduction}

Introducing legumes to the crop rotations of cereals and oil plants enhances agriculture's a sustainable development as part of the EU from-farm-to-fork strategy (Costa et al., 2021). Faba bean acreage covers $2.5 \mathrm{~m}$ ha and comes $5^{\text {th }}$ in the legume sowings, after beans, pea, chickpea and lentil, with its annual production of $4.5 \mathrm{~m}$ tonnes allocated to the production of food, animal feed and green manure production almost across the country (Muktadir et al., 2020, Duc et al., 2015). With Europe's high demand for protein, the Fabaceae sowings account for only $1.5 \%$, and $14.5 \%$ globally; hence a deficit of high-protein feeds in Europe accounting for $70 \%$ (Watson et al., 2017).

Faba bean is a species preferred for cultivation, e.g., in European countries, especially in the north (O'Donovan \& Dunne, 2021), as well as in Egypt (Amany, 2014), Africa (Gezhagen \& Tesfaye, 2017), in Asia (Silim \& Saxena, 2008), and also in Canada (Khazaei et al., 2021). Its distribution across the world shows a good basic capacity for adaptation to various climates (Duc et al., 2015). The primary cultivation objective today, next to the seed yield, is an adaptation of cultivars to drought (Abdellatif et al., 2012; Cernay, 2015; Khazaei et al., 2021) to decrease their yielding variation (Nadeem et al., 2019). Drought contributes to morphological, physiological and biochemical changes at the successive development stages in plants (Abid et al., 2017; Muktadir et al., 2020), which triggers a considerable yield variation in faba bean (Cernay et al., 2015). A high faba bean yielding is accompanied by a high interaction between the cultivar and the environmental conditions (Skovbjerg et al., 2020).

Depending on the pattern of environmental factors, faba bean often changes its structure and plant distribution in the field (Al-Suhaibani et al., 2013). As for agronomic practices, it is important to adjust the adequate row spacing and plant density as well as weed, pest and disease control which are of key importance in limiting the quantitative and qualitative production of legumes (Karkanis et al., 2019). Depending on the plantation site, the 
optimal row spacing for faba bean yielding ranges from $20 \mathrm{~cm}$ (Bakry et al., 2011) to $25 \mathrm{~cm}$ (El-Karamity, 2017) in Egypt and from $30 \mathrm{~cm}$ (Gezahegn et al., 2016; Singh at al., 2013) to $40 \mathrm{~cm}$ (Gezahegn \& Tasfaye, 2017) in Ethiopia. Thalji (2006) found a higher seed yield in faba bean grown with a wider row spacing $(50-70 \mathrm{~cm})$ in the Mediterranean region. According to Raymond et al. (2016), in Australia the 25-50 cm row spacing facilitates a higher faba bean yield than $75 \mathrm{~cm}$ and it has a greater effect on yielding than the plant density.

In Egypt, Amany (2014) recorded higher yields in faba bean with a lower plant density, 25 plants per $\mathrm{m}^{2}$, which was due to a higher number of branches and pods and the seed weight per plant, as well as the seed yield and protein content than for the plant density of 33 plants per $\mathrm{m}^{2}$. El-Karamity et al. (2017) found the highest seed and protein yield in faba bean for the plant density of 33 plants per $\mathrm{m}^{2}$, however, Bakry et al. (2011) reported a considerably higher seed and protein yield, as well as a higher 1000 seed weight after increasing the plant density from 16 to 42 plants per $\mathrm{m}^{2}$. According to López-Bellido et al. (2005), under optimal humidity, a high faba bean yield can be recorded for 20 plants per $\mathrm{m}^{2}$, however under non-optimal conditions, the plant density can increase up to more than 60 plants per $\mathrm{m}^{2}$, which points to a considerable plasticity of faba bean plants.

The aim of the study has been to evaluate the effect of row spacing and plant density on faba bean yielding in the central part of Poland, especially under high humidity and slightly less varied temperature conditions during vegetation period.

The working hypothesis assumes that applying a lower plant density and sowing plants in narrower rows limiting the weed pressure enhance the plant growth, development and yielding.

\section{Materials and Methods}

\subsection{Experimental Site and Design}

A carefully-controlled two-factor field experiment was performed in 2016-2019 at the Experiment Station at Mochelek $\left(53^{\circ} 18^{\prime} 33^{\prime \prime} \mathrm{N}\right.$ and $\left.18^{\circ} 06^{\prime} 67^{\prime \prime} \mathrm{E}\right)$ in Poland, in split-plot in 4 replications and under the soil conditions favourable for faba bean. The soil type, classified according to the WRB, as Haplic Luvissols (Cutanic), was a typical lessive soil formed with light loamy sand, deposited in a shallow layer on light loam (IUSS WRB 2015). The content of phosphorus was very high $\left(90 \mathrm{mg} \mathrm{kg}^{-1}\right.$ of soil), potassium-high (134 $\mathrm{g} \mathrm{kg}^{-1}$ of soil), and magnesium - low (28.7 $\mathrm{g} \mathrm{kg}^{-1}$ of soil). The contents of the available forms of potassium and phosphorus were assayed with the Enger-Rhiem DL method, and magnesium-with the Schachtschabel method. The concentration of nitrate and ammonium nitrate ions was colorimetrically assayed applying the reaction of Behelot and Griess-Ilosvay. The soil $\mathrm{pH}$ was potentiometrically measured in $1 \mathrm{~mol} \mathrm{~L}^{-1} \mathrm{KCl}$. In all the research years, soil $\mathrm{pH}$ was also adequate to faba bean optimal growth (Table 1).

Table 1. Chemical properties of soil measured before sowing faba bean in 2016-2019

\begin{tabular}{|c|c|c|c|c|c|c|}
\hline \multirow{2}{*}{ Years } & \multicolumn{3}{|c|}{ mg per $100 \mathrm{~g}$ of soil } & \multicolumn{2}{|c|}{ mg per kg of soil } & \multirow{2}{*}{$\mathrm{pH}$ in $\mathrm{KCl}$} \\
\hline & $\mathrm{P}_{2} \mathrm{O}_{5}$ & $\mathrm{~K}_{2} \mathrm{O}$ & $\mathrm{Mg}$ & $\mathrm{N}-\mathrm{NO}_{3}$ & $\mathrm{~N}-\mathrm{NH}_{4}$ & \\
\hline 2016 & 109.0 & 127 & 30.0 & 9.53 & 5.73 & 6.3 \\
\hline 2017 & 92.0 & 149 & 31.0 & 5.90 & 7.96 & 6.3 \\
\hline 2018 & 82.0 & 112 & 27.0 & 6.12 & 6.97 & 6.8 \\
\hline 2019 & 77.0 & 149 & 27.0 & 8.69 & 2.27 & 6.5 \\
\hline Mean & 90.0 & 134 & 28.7 & 7.56 & 5.73 & 6.5 \\
\hline
\end{tabular}

\subsection{Land Preparation and Planting}

The research involved a low-tannin non-self-completing "Albus" with the average thousand seed weight of $560 \mathrm{~g}$ and the seed protein content accounting for $29 \%$. Two row spacings $(16$ and $32 \mathrm{~cm})$ and three plant densities (40, 60 and 75 plants per $\mathrm{m}^{2}$ ) were applied. In the successive years, spring wheat was the previous crop. N-30, P-70 and $\mathrm{K}-80 \mathrm{~kg} \mathrm{ha}^{-1}$ fertilisation was applied pre-sowing. The seeds were treated with Vitavax 200 FS seed dressing and Sepiret 3280 Red (polymer). Compliant the producer's guidelines, Nitragina ${ }^{\circledR}$ was used. During development over 4 research years, standard chemical treatments were made to combat dicotyledonous and monocotyledonous weeds, i.e., Linuron and Clomazone in 2016-2018 and Pendimetalina in 2019 (pre-emergence and topdressing) as well as pests, i.e., Thiacloprid + Deltamethin to combat leaf weevils, pod weevils and aphids.

The research years recorded very variable humidity conditions and slightly less variable temperature conditions (Table 2). The most favourable humidity conditions were reported in 2016 and 2017, when the seeds were sown 
on 29 and 23 of March and vegetation period covered 132 and 147 days, respectively. In the two successive years (6 April and 28 March) with a considerably higher air temperature and a lower total rainfall, the vegetation period was similar, 136 and 135 day-long, respectively.

Table 2. Pattern of weather conditions reported in the 2016-2019 research years

\begin{tabular}{lllllll}
\hline \multirow{2}{*}{ Temperature, ${ }^{\circ} \mathrm{C}$} & \multicolumn{7}{c}{ Month } & \multirow{2}{*}{ Mean } \\
\cline { 2 - 6 } & April & May & June & July & August & 15.1 \\
2016 & 8.3 & 14.7 & 17.7 & 18.3 & 16.4 & 14.5 \\
2017 & 6.8 & 13.4 & 16.8 & 17.7 & 17.7 & 17.5 \\
2019 & 12.0 & 16.9 & 18.4 & 20.5 & 19.9 & 16.3 \\
\hline Rainfall, mm & 9.3 & 12.1 & 21.9 & 18.6 & 19.7 & Total \\
\hline 2016 & April & May & June & July & August & 367.3 \\
2017 & 28.7 & 51.4 & 98.1 & 133.8 & 55.3 & 396.4 \\
2018 & 40.8 & 56.3 & 54.3 & 118.9 & 126.1 & 190.7 \\
2019 & 40.4 & 14.2 & 26.4 & 86.0 & 23.7 & 168.5 \\
\hline
\end{tabular}

At the full flowering stage (BBCH 65), the SunScan Canopy Analysis System ( $\Delta$ T Devices Ltd., UK) was used to determine the LAI (Leaf Area Index) whereas the N-tester - the content of chlorophyll in leaves. Right before harvest, the number of pods per plant, the number of seeds per pod, the weight of seeds per pod and 1000 seed weight were evaluated. Also, the yield of the dry weight of straw from each plot was assessed to calculate the HI (Harvest Index) as well as SPAD (Soil Plant Analysis Development) to measure the crop nitrogen status. At the end, the content and the yield of protein was measured.

\subsection{Statistical Analysis}

The experiment was a 2-factorial analysis fitted into completely randomized block design with four replications. The data was processed with ANOVA using STATISTICA version 10 (StatSoft, Tulsa, OK, U.S.). The $p<0.05$ and $p<0.01$ and $p<0.001$ were set as the level of significance. The Tuckey's HDS test at $p<0.05$ was used for the difference between parameter means. Pearson's correlation coefficients were applied for the relationship between the parameters. The means in tables and charts provided with the same letters did not differ significantly.

\section{Results and Discussion}

In general, legumes show a high sensitivity to water stress, which leads to a lower germinability and plant emergence, growth inhibition, a serious damage to photosynthetic apparatus, a decreased photosynthesis net and nutrient absorption. In many countries, the faba bean adaptation to drought is the key breeding objective (Abdellatif et al., 2012; Cernay, 2015; Khazaei et al., 2021). Another way to produce high and stable across-the-years yields in faba bean is irrigation, which, however, can increase the cultivation costs essentially (Thalji, 2003). A variation in faba bean yielding is one of the reasons for abandoning or limiting the cultivation of legumes in general, including faba bean, in Europe, which means a limited possibility of using atmospheric N, or limiting the costs of growing successive crops and an increase in their yielding with lower rates of mineral $\mathrm{N}$ (Zander et al., 2016). Under favourable humidity conditions the faba bean yields in Ireland reach up to $8 \mathrm{t}^{-1}$ (O'Donovan \& Dunne, 2021). In the present research there has been a significant impact of the weather pattern on faba bean yielding. In 2016 and 2017, with a high and well-distributed total rainfall the seed yield was very high, above $6 \mathrm{t}$ per ha, while in the dry years of 2018 and 2019-0.69 and $2.14 \mathrm{tha}^{-1}$, respectively. Nadeem et al. (2019) claim that stress triggered by drought is, indeed, a challenge for agricultural crops and it has been considered a cause of a very serious limitation to plant productivity in general and, at the same time, it is considered to be even more intensive and severe in the nearest future. In the present research with vary variable humidity conditions across the research years, there was found, similarly to Gezahegn et al. (2019), a significant impact of the total rainfall in June, as well as a high impact in July and August on faba bean yielding (Table 3). Also, Sobko et al. (2020) found a positive correlation between the seed yield and the rainfall total and distribution during flowering — seed filling and ripening, when the Fabaceae plants are especially sensitive to water deficit. 
Table 3. Pearson correlation coefficient for the total rainfall across the months and the seed yield in 2016-2019

\begin{tabular}{ll}
\hline Month & \\
\hline March & $0.427^{\mathrm{ns}}$ \\
April & $0.256^{\mathrm{ns}}$ \\
May & $0.232^{\mathrm{ns}}$ \\
June & $0.832^{*}$ \\
July & $0.726^{\mathrm{ns}}$ \\
August & $0.767^{\mathrm{ns}}$ \\
June-August & $0.915^{*}$ \\
\hline
\end{tabular}

According to Vadez et al. (2012), an increase in the air temperature accelerates the beginning of flowering and shortens the vegetation period by increasing evapotranspiration, which does not give an opportunity for increasing the seed yield either. In the present research a high air temperature mean in June and in July $2018\left(18.4{ }^{\circ} \mathrm{C}\right.$ and 20.5 $\left.{ }^{\circ} \mathrm{C}\right)$ and $2019\left(21.9^{\circ} \mathrm{C}\right.$ and $\left.18.6{ }^{\circ} \mathrm{C}\right)$, next to lower total rainfall, decreased the faba bean yielding considerably. The applicable literature provides a series of optimal yet country-and-geographic-location-specific row spacings for faba bean growing; from $20 \mathrm{~cm}$ to $40 \mathrm{~cm}$ closer to the Equator (Bakry et al., 2011; El-Karamity, 2017; Gezahgen \& Tasfaye, 2017), to as much as $25 / 50 \mathrm{~cm}$ in Australia (Raymond et al., 2016). In Jordan, in the Mediterranean region, Thalji (2006) recorded a higher faba bean yield due to a higher weight of the seeds when produced with a increased row spacing $(50-70 \mathrm{~cm})$.

In the present research, on the other hand, the row spacing applied in Poland, 16 and $32 \mathrm{~cm}$, in none of the 4 research years significantly differentiated the yield of faba bean which was quite high and $4.01 \mathrm{tha}^{-1}$ on average (Table 4). With a lower row spacing, one can expect a lower pressure of weeds in rows, which can make the application of herbicides less necessary. With the above dependencies, one can assume a hypothesis that the optimal row spacing for faba bean growing will depend on the latitude of geographical latitude of established plantations, however, surely also on the rainfall total and distribution as well as on the air temperature during plant development and growth. It is seen from a higher yield of faba bean grown with lower row spacing and with a higher plant density in the season with a limited rainfall total and distribution (Simil \& Saxena, 2008).

According to Al-Suhaibani et al. (2013), the optimal plant density has a significant effect on the yielding and the structural yield components in faba bean, however, again, depending on the growing location and the date of sowing, in autumn or in spring, it varies considerably (Lopez-Bellido et al., 2005). Most observations show that the optimal plant density ranges from 25-33 plants per $\mathrm{m}^{2}$ in the regions closer to the Equator (Singh et al., 2013; Amany, 2014; El-Karamity et al., 2017) - to up to 42 plants per $\mathrm{m}^{2}$ (Bakry et al., 2011), although, e.g., in Syria, in the season with limited rainfall, the highest yields were harvested not only as a result of a lower row spacing but also a higher sowing rate, which made the water uptake, evapotranspiration and water use more effective (Silim \& Saxena, 2008). In Spain, under favourable humidity and autumn sowing, a high faba bean yield can be recorded for the plant density of 20 plants (López-Bellido et al., 2005), and even 15 plants per $\mathrm{m}^{2}$ in Iran (Fakhr et al., 2020). However, as for the spring date of faba bean sowing typical for the temperate climate conditions, the optimal plant density is higher due to a shorter vegetation period (López-Bellido et al., 2020). Increasing the plant density from 49 to 67 plants per $\mathrm{m}^{2}$ guaranteed a significant increase in the faba bean seed yield, especially under non-optimal humidity conditions (Prusiński, 2003). In the present research only in 2019 and on average in the multi-year period, a higher plant density $\left(60\right.$ and 75 plants per $\left.\mathrm{m}^{2}\right)$ ensured similar yet significantly higher faba bean seed yields than the plant density of 45 plants per $\mathrm{m}^{2}$ (Table 4 ). 
Table 4. Average 4-year faba bean seed yield $\left(\mathrm{t} \mathrm{ha}^{-1}\right)$ depending on row spacing and plant density

\begin{tabular}{|c|c|c|c|c|c|c|}
\hline \multirow{2}{*}{ Factors } & & \multicolumn{4}{|c|}{ Year } & \multirow{2}{*}{ Mean } \\
\hline & & 2016 & 2017 & 2018 & 2019 & \\
\hline \multirow{2}{*}{ Row spacing $\mathrm{cm}(\mathrm{R})$} & 16 & 6.60 & 6.65 & 0.67 & 2.13 & 4.01 \\
\hline & 32 & 6.69 & 6.52 & 0.71 & 2.14 & 4.02 \\
\hline \multirow{3}{*}{ Plant density (D) } & 45 & 6.50 & 6.45 & 0.65 & $1.97 \mathrm{~b}$ & $3.89 \mathrm{~b}$ \\
\hline & 60 & 6.65 & 6.69 & 0.71 & $2.16 \mathrm{a}$ & $4.05 \mathrm{a}$ \\
\hline & 75 & 6.78 & 6.62 & 0.70 & $2.28 \mathrm{a}$ & $4.10 \mathrm{a}$ \\
\hline \multirow[t]{4}{*}{ Mean } & & $6.64 \mathrm{~A}$ & $6.59 \mathrm{~A}$ & $0.69 \mathrm{C}$ & $2.14 \mathrm{~B}$ & 4.01 \\
\hline & $\mathrm{R}$ & ns & $\mathrm{ns}$ & ns & ns & ns \\
\hline & $\mathrm{D}$ & ns & ns & ns & $*$ & $*$ \\
\hline & $\mathrm{R} \times \mathrm{D}$ & $*$ & ns & ns & ns & ns \\
\hline
\end{tabular}

Note. Values of a parameter followed by the same letter did not differ significantly for the year, row spacing and density (ANOVA followed by Tuckey's HDS test, $\mathrm{p}<0.05$ ). ANOVA results: $* * * \mathrm{p}<0.001 ; * * \mathrm{p}<0.01 ;{ }^{*} \mathrm{p}<$ 0.05 ; ns, non-significant.

Under favourable conditions in terms of rainfall total and distribution in 2016 and 2017, in addition to the seed yield, the values of the structural yield components were also significantly higher than in the dry years of 2018 and 2019 (Table 5). According to López-Bellido et al. (2000), the number of pods per plant is one of the most sensitive and variable legume seed yield components. The average number of pods per plant was 6.52 , and the row spacing did not differentiate the values significantly. A significantly higher number of pods was recorded when the lowest plant density was used, $15.8 \%$ and $21.4 \%$ higher, respectively, compared with the density of pods per plant growing with the average and the highest density. No such dependencies, however, were found for the other yielding components. The average number of seeds per pod in faba bean was 2.86 , and the seed weight per pod- $1.46 \mathrm{~g}$, while the 1000 seed weight $-507 \mathrm{~g}$. The values did not depend significantly on any of the factors applied in the experiment. However, Esho and Salih (2021) reported a direct positive effect on faba bean yielding being the number of pods per plant and 1000 seed weight, and according to Singh et al. (2021), also the weight of pods per plant. Yucel et al. (2013) have found that all the above faba bean components determining the seed yield depend on the total rainfall, which coincides with the results of the present research, however only for June and a period of June-August.

Table 5. Average 4-year faba bean yielding components depending on row spacing and plant density in 2016-2019

\begin{tabular}{|c|c|c|c|c|c|}
\hline Factors & & Number of pods per plant & Number of seeds per pod & Weight of seeds per pod, $g$ & Thousand seed yield, $\mathrm{g}$ \\
\hline \multirow{4}{*}{ Year $(\mathrm{Y})$} & 2016 & $10.4 \mathrm{a}$ & $3.05 \mathrm{a}$ & $1.63 \mathrm{~b}$ & $533 \mathrm{~b}$ \\
\hline & 2017 & $7.01 \mathrm{~b}$ & $3.16 \mathrm{a}$ & $1.85 \mathrm{a}$ & $585 \mathrm{a}$ \\
\hline & 2018 & $3.45 \mathrm{~d}$ & $2.47 \mathrm{c}$ & $1.19 \mathrm{c}$ & $479 \mathrm{c}$ \\
\hline & 2019 & $5.20 \mathrm{c}$ & $2.77 \mathrm{~b}$ & $1.19 \mathrm{c}$ & $432 \mathrm{~d}$ \\
\hline \multirow{3}{*}{ Row spacing $(\mathrm{cm})(\mathrm{R})$} & 16 & 6.24 & 2.86 & 1.47 & 513 \\
\hline & 32 & 6.83 & 2.87 & 1.46 & 502 \\
\hline & 45 & $7.44 \mathrm{a}$ & 2.90 & 1.49 & 508 \\
\hline \multirow[t]{10}{*}{ Plant density (D) } & 60 & $6.26 \mathrm{~b}$ & 2.82 & 1.43 & 504 \\
\hline & 75 & $5.85 \mathrm{~b}$ & 2.86 & 1.47 & 510 \\
\hline & Mean & 6.52 & 2.86 & 1.46 & 507 \\
\hline & $\mathrm{Y}$ & $* * *$ & $* * *$ & $* * *$ & $* * *$ \\
\hline & $\mathrm{R}$ & $* *$ & ns & ns & ns \\
\hline & $\mathrm{D}$ & $* * *$ & ns & $\mathrm{ns}$ & $\mathrm{ns}$ \\
\hline & $\mathrm{Y} \times \mathrm{R}$ & ns & ns & ns & ns \\
\hline & $\mathrm{Y} \times \mathrm{D}$ & $* *$ & ns & ns & ns \\
\hline & $\mathrm{R} \times \mathrm{D}$ & $* *$ & ns & $\mathrm{ns}$ & ns \\
\hline & $\mathrm{Y} \times \mathrm{R} \times \mathrm{D}$ & $*$ & ns & $\mathrm{ns}$ & ns \\
\hline
\end{tabular}

Note. Values of a parameter followed by the same letter did not differ significantly for the year, row spacing and density (ANOVA followed by Tuckey's HDS test, $\mathrm{p}<0.05$ ). ANOVA results: $* * * \mathrm{p}<0.001 ; * * \mathrm{p}<0.01 ;{ }^{*} \mathrm{p}<$ 0.05 ; ns, non-significant. 
The weather pattern across the years was also significant for the values of the HI, LAI, SPAD, protein content and protein yield (Table 6). As for the share of the seed yield and straw in faba bean, the HI (Harvest Index) accounted for $56.8 \%$ and it was significantly highest in the most humid vegetation periods in 2016 and 2017. The row spacing and plant density in faba bean did not differentiate the value of the $\mathrm{HI}$ index. Fakhr et al. (2020) report on the significantly highest $\mathrm{HI}$ value recorded for the density of 15 plants per $\mathrm{m}^{2}$, which was not observed in the present research.

In the present research the Leaf Area Index (LAI) value was low and only 2.06 on average, however, in humid years with well-distributed rainfall, 2016 and 2017, it was significantly, on average about 3-fold higher than in 2018 and 2019 with high water deficit. Kulig et al. (2007) found that decreasing the plant density in faba bean makes the plants unable to compensate for the LAI value. However, in the present research the plant density did not differentiate the LAI value, however, the value was significantly higher, by $22.7 \%$, when faba bean was grown in narrow rows. According to Gezahegn et al. (2016), a greater row width $(50 \mathrm{~cm})$ resulted in a decrease in the LAI value. The average, evaluated with the chlorophyll meter, leaf greenness index in faba bean in 4 research years was 44.5 SPAD units. The significantly highest value was recorded in the dry year 2018, however, none of the two factors applied, row spacing and plant density, did not differentiate it significantly. Due to the ability to fix atmospheric N, faba bean seeds demonstrate a high protein content and they are a source of nutrients, vitamins and many bioactive compounds (Karkanis et al., 2019). In Europe the average protein content in faba bean seeds accounts for about 30\% (Skovbjerg et al., 2020), similarly as, e.g., in Canada; $24-35 \%$ of dry weight (Khazaei et al., 2021). In the present research the protein content in faba bean seeds was $29.2 \%$ on average, and the protein yield was $1248 \mathrm{~kg}$ per ha on average, from $200-600 \mathrm{~kg}$ in extremely dry years to over $2000 \mathrm{~kg} \mathrm{ha}^{-1}$ in humid years.

Table 6. HI, LAI, SPAD, protein content and protein yield in faba bean depending on row spacing and plant density in $2016,2017,2018$ and 2019

\begin{tabular}{|c|c|c|c|c|c|c|}
\hline Factors & & $\mathrm{HI}$ & LAI & SPAD & Protein content $\%$ & Protein yield, $\mathrm{kg} \mathrm{ha}^{-1}$ \\
\hline \multirow{4}{*}{ Year $(Y)$} & 2016 & $63.7 \mathrm{a}$ & $3.13 \mathrm{a}$ & $40.2 \mathrm{~b}$ & $31.4 \mathrm{a}$ & $2093 \mathrm{a}$ \\
\hline & 2017 & $65.5 \mathrm{a}$ & $3.13 \mathrm{a}$ & $41.1 \mathrm{~b}$ & $31.4 \mathrm{a}$ & $2098 \mathrm{a}$ \\
\hline & 2018 & $46.4 \mathrm{c}$ & $0.67 \mathrm{~b}$ & $56.4 \mathrm{a}$ & $26.3 \mathrm{~b}$ & $204 \mathrm{c}$ \\
\hline & 2019 & $51.7 \mathrm{~b}$ & $1.33 \mathrm{c}$ & $40.3 \mathrm{~b}$ & $27.5 \mathrm{~b}$ & $599 \mathrm{~b}$ \\
\hline \multirow{3}{*}{ Row spacing cm (R) } & 16 & 56.6 & $2.33 \mathrm{a}$ & 44.4 & 29.0 & 1238 \\
\hline & 32 & 56.1 & $1.80 \mathrm{~b}$ & 44.7 & 29.3 & 1259 \\
\hline & 45 & 56.8 & 2.13 & 45.3 & 29.4 & 1228 \\
\hline \multirow[t]{10}{*}{ Plant density (D) } & 60 & 56.0 & 1.88 & 44.5 & 29.3 & 1263 \\
\hline & 75 & 57.7 & 2.18 & 43.7 & 28.7 & 1255 \\
\hline & Mean & 56.8 & 2.06 & 44.5 & 29.2 & 1248 \\
\hline & $\mathrm{Y}$ & $* * *$ & $* * *$ & $* * *$ & $* * *$ & $* * *$ \\
\hline & $\mathrm{R}$ & ns & $* * *$ & ns & ns & ns \\
\hline & $\mathrm{D}$ & ns & ns & ns & ns & ns \\
\hline & $\mathrm{Y} \times \mathrm{R}$ & ns & ns & ns & ns & ns \\
\hline & $\mathrm{Y} \times \mathrm{D}$ & $* * *$ & ns & ns & ns & ns \\
\hline & $\mathrm{R} \times \mathrm{D}$ & ns & ns & $\mathrm{ns}$ & ns & $\mathrm{ns}$ \\
\hline & $\mathrm{Y} \times \mathrm{R} \times \mathrm{D}$ & $* * *$ & ns & ns & ns & ns \\
\hline
\end{tabular}

Note. Values of a parameter followed by the same letter did not differ significantly for the year, row spacing and density (ANOVA followed by Tuckey's HDS test, $\mathrm{p}<0.05$ ). ANOVA results: *** $\mathrm{p}<0.001 ; * * \mathrm{p}<0.01 ; * \mathrm{p}<$ 0.05 ; ns, non-significant.

Abid et al. (2017) claim that even though drought stress and water deficit in soil limits the plant growth, it can increase the content of protein in faba bean seeds significantly. In the contrary, in the present study, in more favourable-in-terms-of-rainfall years, 2016-2017, the protein content was significantly higher than in years with essential rainfall deficit (2018 and 2019). According to El-Karamity et al. (2017), $20 \mathrm{~cm}$ row spacing guaranteed the highest protein yield, which was, however, considerably lower (550-550 $\left.\mathrm{kg} \mathrm{h}^{-1}\right)$ than in the present research, while increasing the plant density resulted in its decrease, which was not confirmed in the present research either. 
Considerable highly-significant dependencies expressed with a positive value of the Pearson coefficient were found between the seed yield and, respectively, the number of pods, the number and weight of seeds per pod and thousand seed weight (Table 7). The number of pods per plant was negatively significantly correlated with the plant density prior to harvest and significantly with the other faba bean yield structure components. Kumar et al. (2017) have demonstrated that all the characteristics showed a positively significant value of the coefficient of correlation with the seed yield; hence 1000 seed weight, the number of pods and seeds per pod and 1000 seed weight per plant have an immediate effect on faba bean yielding. The results reported by Gidey (2016) also point to a significant importance of the number of seeds per pod and the number of pods per plant for faba bean yielding. As reported, the 1000 seed weight was negatively correlated with the number of pods per plant, which, however, has not been recorded in the present research.

Table 7. Correlation matrix (Pearson) between the parameters studied $(n=192)$

\begin{tabular}{llllll}
\hline & Seed yield & Pods per plant & Seeds per pod & Seed weight per pod & Weight of 1000 seeds \\
\hline Pods per plant & $0.737^{* *}$ & & & \\
Seeds per pod & $0.758^{* *}$ & $0.573^{* *}$ & & \\
Seed weight per pod & $0.840^{* *}$ & $0.555^{* *}$ & $0.847^{* *}$ & \\
Weight of 1000 seeds & $0.699^{* *}$ & $0.410^{* *}$ & $0.505^{* *}$ & $0.884^{* *}$ & \\
Density prior to harvest & $-0.034^{\text {ns }}$ & $-0.389^{* *}$ & $0.025^{\mathrm{ns}}$ & $0.098^{\mathrm{ns}}$ & $0.133^{\mathrm{ns}}$ \\
\hline
\end{tabular}

Note. ${ }^{* *} p<0.01 ; * p<0.05 ;$ ns, non-significant.

The results of the analysis of regression (Table 8) show that the essential components which determine the faba bean yielding are, in the following order: seed weight per pod (70.5\%), the number of seeds per pod $(54.5 \%)$, the number of pods per plant (54.3\%) and 1000 seed weight (48.9\%), which coincides with the results of the research reported by Esho and Salih (2021) and by Singh et al. (2021). According to Tivari and Singh (2019), the faba bean seed yield points to a significant value of the correlation with all the components, except for 1000 seeds. There is, therefore, a wide scope for improvement of the efficiency and seed yield structure components, especially the number of pods per plant or the number and the width of pods. The components should be used for selecting new, elite genotypes of faba bean.

Table 8. Regression analysis for the parameters under study $(\mathrm{n}=192)$

\begin{tabular}{llll}
\hline Parameter & Regression Equation & $\mathrm{R}^{2}$ & $\mathrm{R}$ \\
\hline Seed yield & & & \\
Pod per plant & $\mathrm{y}=3.1874+0.8306 \times \mathrm{x}$ & 0.543 & $0.737^{* *}$ \\
Seed per pod & $\mathrm{y}=2.4711+0.0974 \times \mathrm{x}$ & 0.545 & $0.758^{* *}$ \\
Seed weight per pod & $\mathrm{y}=1.0606+0.1004 \times \mathrm{x}$ & 0,705 & $0.840^{* *}$ \\
1000 seed weight & $\mathrm{y}=436.4171+17.6614 \times \mathrm{x}$ & 0.489 & $0.699^{* *}$ \\
Plant density prior to harvest & $\mathrm{y}=57.4757-0.1924 \times \mathrm{x}$ & 0.001 & $-0.034^{\mathrm{ns}}$ \\
\hline
\end{tabular}

Note. ${ }^{* *} p<0.01 ; * p<0.05 ;$ ns, non-significant.

\section{Conclusions}

The success of faba bean growing was mostly determined by the total rainfall during growth and generative development in successive years. The results of the present research and the research cited from various parts of Europe and the world point to the application of various row spacings and plant densities for growing faba bean sown in autumn and in spring. The faba bean seed yield did not depend on any of the studied factors significantly, which can point to a possibility of using the lowest, of all the studied ones, plant density per $\mathrm{m}^{2}$ and a narrow row spacing. Both features are important in terms of a lower sowing material consumption and a faster and more effective weed control in a faba bean field. Due to very different water and temperature conditions, also the structural yield components varied a lot, and partially differed from those reported in other countries and on other continents. Finally, the research hypothesis was not confirmed. Plant density and row spacing (except for one year) did not significantly differentiate the faba bean seed yield over the years. 


\section{Acknowledgements}

This study was made possible by a grant of the Polish Ministry of Agriculture and Rural Development, Project No. HOR 3.3.2.2016-2020. Distribution of plants in the canopy, yielding and seed quality of the most fertile varieties of peas, faba bean, white lupine and soybean in different regions of the country.

\section{References}

Abdellatif, K. F., Absawy, E. S., \& Zakaria, A. M. (2012). Drought stress tolerance of faba bean as studied by morphological traits and seed storage protein pattern. Journal of Plant Studies, 1(2), 47-54. https://doi.org/10.5539/jps.v1n2p47

Abid, G., Hessini, K., Aouida, M., Aroua, I., Baudoin, J. P., Muhovski, Y., ... Jebara, M. (2017). Agro-physiological and biochemical responses of faba bean (Vicia faba L. var. 'minor') genotypes to water deficit stress. BASE Biotechnol. Agron. Soc. Environ., 21(2), 146-159. https://doi.org/10.25518/ $1780-4507.13579$

Al-Suhaibani, N., El-Hendawy, S., \& Schmdhalter, U. (2013). Influence of varied plant density on growth, yield and economic return of drip irrigated faba bean (Vicia faba L.). Turkish Journal of Field Crops, 18(2), 185-197.

Amany, M. A. (2014). Response of faba bean (Vicia faba L.) to different planting densities and bio-mineral fertilization systems. American-Eurasian J. Agric. and Environ. Sci., 14(6), 541-545.

Bakry, B. A., Elewa, T. A., El Karamany, M. F., Zeidan, M. S., \& Tawfik, M. M. (2011). Effect of row spacing on yield and its components of some faba bean varieties under newly reclaimed sandy soil conditions. World Journal of Agricultural Sciences, 7(1), 68-72.

Cernay, C., Ben-Ari, T., Pelzer, E., Meynard, J. M., \& Makowski, D. (2015). Estimating variability in grain legume yields across Europe and the Americas. Scientific Reports, 5, 11171. https://oi.org/10.1038/ srep11171

Costa, M. P., Reckling, M., Chadwick, D. R., Rees, R. M., Saget, S., Williams, M. L., \& Styles, D. (2021). Legume-modified rotations deliver nutrition with lower environmental impact. Front. Sustain. Food Syst., 13. https://doi.org/10.3389/fsufs.2021.656005

Duc, G., Aleksić, J. M., Marget, P., Mikic, A., Paull, J., Redden, R. J., ... Torres, A. M. (2015). Faba bean. In A. Ron (Ed.), Grain legumes. Handbook of plant breeding (Vol. 10, pp. 141-178). Springer, New York, NY, USA. https://doi.org/10.1007/978-1-4939-2797-5-5

El-Karamity, A. E., Abdullah, S. Sh., \& El-Ridwany, A. R. (2017). Effect of plant distribution and density on yield and yield components of some faba bean (Vicia faba L.) cultivars. Minia J. of Agric. Res. \& Develop., 37(2), 211-230.

Esho, K. B., Salih, M. M. (2021). Correlation and path coefficient analysis in faba bean (Vicia faba L.). Plant Cell Biotechnology and Molecular Biology, 22, 53-62.

Fakhr, S. K. M., Fotouhi, F., Khaniani, B. H., Sadeghi, M., \& Zadeh, S. A. F. (2019). Effect of planting date and density on yield and yield components of bean genotypes (Vicia faba L.). Legume Research-An International Journal, 43, 672-677.

Gezahegn, A. M. (2019). Review on effect of plant density and planting arrangement on faba bean production. World Journal of Agricultural Sciences, 15(4), 261-268. https://doi.org/10.5829/idosi.wjas.2019.261.268

Gezahegn, A. M., \& Tesfaye, K. (2017). Optimum inter and intra row spacing for faba bean production under Fluvisols. MAYFEB Journal of Agricultural Science, 4, 10-19.

Gidey, B. A. (2016). Variability of large seeded faba bean genotypes for their yield and yield components in water logging areas of southern Tigray, Ethiopia (2016). International Journal of Research Studies in Agricultural Sciences, 2(8), 1-8. https://doi.org/10.20431/2454-6224.0208001

IUSS Working Group WRB. (2015). World Reference Base for Soil Resources 2014, update 2015. International Soil Classification System for Naming Soils and Creating Legends for Soil Maps. World Soil Resources Reports No. 106. Rome, Food and Agriculture Organization.

Karkanis, A., Ntatsi, G., Lepse, L., Fernandez, J. A., Vagen, I. M., Rewald, B., .. Savvas, D. (2018). Faba bean cultivation-Revealing novel managing practices for more sustainable and competitive European cropping system. Frontiers in Plant Science, 9, 1115. https://doi.org/103389/fpls. 2018.01115 
Khazaei, H., Hawkins, G., \& Vandenberg, A. (2021). Historical review of faba bean improvement in western Canada. Legume Science Canada, e92. https://doi.org/10.1002/leg3.92

Kulig, B., Pisulewska, E., \& Sajdak, A. (2007). Effect of sowing rate on the yield and size of assimilation area in selected field bean cultivars. Zesz. Probl. Post. Nauk Rol., 522, 263-270.

Kumar, P., Das, R. R., Bishnoi, S. K., \& Sharma, V. (2017). Inter-correlation and path analysis in faba bean (Vicia faba L.). Electronic Journal of Plant Breeding, 8(1), 395-397. https://doi.org/10.5958/0975-928X. 2017.00059.X

Lopez-Bellido, F. J., Lopez-Bellido, L., \& Lopez-Bellido, R. J. (2005). Competition, growth and yield of faba bean (Vicia faba L.). European Journal of Agronomy, 23(4), 359-378. https://doi.org/10.1016/j.eja. 2005.02.002

Muktadir, M. A., Adhikari, K. N., Merchant, A., Belachew, K. Y., Vandenberg, A., Stoddard, F. L., \& Khazaei, H. (2020). Physiological and biochemical basis of faba bean breeding for drought adaptation: A review. Agronomy, 10, 1345. https://doi.org/10.3390/agronomy10091345

Nadeem, M., Li, J., Muhammad, Y., Yahya, M., Sher, A., Ma, C., ... Oiu, L. (2019). Research progress and perspective on drought stress in legumes: A review. Int. J. Mol. Sci., 20(10), 2541. https://doi.org/ 103390/ijms20102541

O’Donovan, T., \& Dunne, D. (2021). Establishing high-yielding faba bean. Establishing high-yielding faba bean. Exploiting high yield potential in north-west Europe. Legumes Translated Practice Note, 8. Retrieved from https://www.legumestranslated.eu

Prusiński, J. (2003). Effect of plant density on the yielding of determinate varieties of faba bean (Vicia faba ssp. minor) grown in light soil. Acta Scientiarum Polonorum, Agricultura 2(2), 107-118.

Raymond, R., McKenzie, K., \& Rachaputi, R. C. N. (2016). Faba bean agronomy: Ideal row spacing and time of sowing (Mb: 0428879 900). Grains Research and Development Corporation, Department of Agriculture and Fisheries, Queensland, Australia.

Silim, S. N., \& Saxena, M. C. (2008). Yield and water use efficiency of faba bean sown at two row spacing and seed densities. Experimental Agriculture, 29(2), 173-181. https://doi.org/10.1017/ S0014479700020615

Singh, A. K., Bhatt, B. P., Sundaram, P. K., Gupta, A. K., \& Singh, D. (2013). Planting geometry to optimize growth and productivity in faba bean (Vicia faba L.) and soil fertility. Journal of Environmental Biology, 34, 117-122.

Singh, D. V., Nath, S., Singh, S. P., Mishra, U., \& Singh, S. (2021). Character association correlation and path coefficient analysis in Faba bean (Vicia faba L.). The Pharma Innovation Journal, 10(4), 517-520. https://doi.org/10.22271/tpi.2021.v10.i4g.5982

Skovbjerg, C. K., Knudsen, J. N., Fuchtbauerjens, W., Frederick, S., Stodddard, L., Stig, L. J., \& Andersen, U. (2020). Evaluation of yield, yield stability and yield-protein relationship in 17 commercial faba bean cultivars. Legume Science, 2(3), 1-11. https://doi.org/10.1002/leg3.39

Sobko, O., Hartung, J., Zikeli, S., Claupein, W., \& Gruber, S. (2019): Effect of sowing density on grain yield, protein and oil content and plant morphology of soybean (Glycine max L. Merrill). Plant, Soil and Environment, 65, 594-601. https://doi.org/10.17221/346/2019-PSE

Thalji, T. (2006). Impacts of row spacing on faba bean L. Growth under Mediterranean rainfed conditions. Journal of Agronomy, 5, 527-532. https://doi.org/10.3923/ja.2006.527.532

Tivari, Y. K., \& Singh, A. K. (2019). Principal component analysis for yield and yield traits of faba bean (Vicia faba L.). Journal of Food Legumes, 32(1), 13-15.

Vadez, V., Berger, J. D., Warkentin, T., Asseng, S., Ratnakumar, P., Rao, K. C., ... Zaman, M. A. (2012). Adaptation of grain legumes to climate change: A review. Agronomy of Sustainable Development, 32, 31-44. https://doi.org/10.1007/s13593-011-0020-6

Watson, C. A., Reckling, M., Preissel, S., Bachinger, J., Bergkvist, G., Kuhlman, T., ... Stoddard, F. L. (2017). Chapter Four: Grain legume production and use in European agricultural systems. Advances in Agronomy, 144, 235-303. https://doi.org/10.1016/bs.agron.2017.03.003

Yucel, D. O. (2013). Optimal intra-row spacing for production of local faba bean (Vicia faba L. major) cultivars in the Mediterranean conditions. Pak. J. Bot., 45(6), 1933-1938. 
Zander, P., Amjath-Babu, T. S., Preissel, S., Reckling, M., Bues, A., Schläfke, N., ... Watson, Ch. (2016). Grain legume decline and potential recovery in European agriculture: A review. Agron. Sustain. Dev., $36,26$. https://doi.org/10.1007/s13593-016-0365y

\section{Copyrights}

Copyright for this article is retained by the author(s), with first publication rights granted to the journal.

This is an open-access article distributed under the terms and conditions of the Creative Commons Attribution license (http://creativecommons.org/licenses/by/4.0/). 